\title{
EFFECTIVE FINANCIAL CONTROL DEVELOPMENT OF MANAGING SUBJECTS
}

\section{РОЗВИТОК ЕФЕКТИВНОГО ФІНАНСОВОГО КОНТРОЛЮ СУБ'ЄКТІВ ГОСПОДАРЮВАННЯ}

\section{Datsenko Hanna ${ }^{1}$}

DOI: https://doi.org/10.30525/978-9934-571-78-7_5

Abstract. The purpose of the paper is to systematize the scientists views on understanding the essence of the concept of «financial control», which allows not only to carry out research of purely methodological aspects of the management activities implementation, and to ensure the development of applied issues of its improvement. Methodology. The survey is based on a historical analysis and theoretical generalization during the study of the peculiarities of the scientific views development on the financial control of economic entities; abstract-logical method is used for the logical formation of the basic principles and implications of the research, and substantiation of the concept of financial control at the level of economic entities; the method of analogy is used to compare trends in the development of existing approaches of control; system analysis - for finding out the problems of organization and development of financial control of economic entities; structural-financial - for the description and explanation of the structured construction and development of the financial control system of economic entities; graphic - for visual illustration and construction of diagrams and graphs according to the research method. Results of the survey showed advantages of a systematic approach to defining the concept of «financial control», which enables the hierarchy formation of all elements of the management activity. Therefore, the study of the genesis of scientific approaches in the definition of the term «financial control» confirms the implementation of its management function only in the form of an independent system. According to the results of the research a distinction was made between financial control at the macro, meso- and macro levels.

${ }^{1}$ Candidate of Economic Sciences,

Applicant of Scientific Degree of Doctor of Economic Sciences,

Khmelnytskyi National University, Ukraine 


\section{Chapter «Economic sciences»}

Schematic representation of the structural construction of the financial control system was made, which contains elements, that collectively provide for its efficiency and effectiveness of functioning. The use of a systematic approach to determining the main components of the financial control allowed to construct a structural framework for financial control at the level of economic entities, with a distinction being made between the main tasks of carrying out, the subject-object structure, the tools and the implementation levers. This should ensure positive results both for business entities and for the state as a whole.

\section{1. Ветуп}

3 огляду на швидку зміну ринкової кон'юнктури на світових фінансових ринках, нестабільність внутрішнього і зовнішнього середовища, а також затяжний етап подолання фінансово-економічної кризи, на якому наразі перебуває вітчизняний фінансовий ринок, здійснювати його контроль стає дедалі складніше. У зв'язку із цим, не викликає сумнівів актуальність дослідження, що спрямоване на розкриття сутності фінансового контролю суб'єктів господарювання, виявленні його особливостей функціонування та розвитку, важелів впливу та основних інструментів реалізації.

Водночас за сучасних реалій функціонування вітчизняних підприємств, які зазнали тривалого періоду трансформацій, відбувається перегляд традиційних підходів до їх управління. Існування великої кількості підприємств з різною формою власності, що створює передумови до появи нових видів порушень фінансового характеру, викликає необхідність організування належним чином фінансового контролю як важливого структурного компоненту реалізації господарської діяльності сучасних підприємств. Уміло організований фінансовий контроль здатний забезпечити раціональне використання матеріальних і фінансових ресурсів на підприємствах, збереження майна, отримання високої результативності від ведення господарської діяльності, належний рівень фінансової безпеки та дотримання принципів законності в їх діяльності.

На сьогодні в Україні існує низка проблем у реалізації фінансового контролю, які полягають у неефективному його здійсненні, що породжує необхідність удосконалення організаційного, технічного, економічного, юридичного та обліково-аналітичного забезпечення контрольної діяльності. 


\section{Datsenko Hanna}

Основна проблема системи фінансового контролю суб'єктів господа-рювання полягає у недосконалості законодавства. Це спричинено тим, що система внутрішнього контролю України функціонує без існування базового закону, на який можна було би посилатися при визначенні основних понять у цій сфері, чіткому розподіленні завдань, делегуванні функцій та повноважень між органами державної та місцевої влади, регламентуванні відносин між суб'єктами та об'єктами контролю.

На початковому етапі при здійсненні фінансового контролю на підприємстві з першою перешкодою, що зіштовхуються суб'єкти контролю, є відсутність базового для цієї сфери відносин Закону України «Про державний фінансовий контроль».

Не дивлячись на активне обговорення зазначеного законопроекту багатьма науковцями і практиками протягом тривалого періоду, все ж залишилась низка питань, зокрема, суто методологічного характеру, які не до кінця вирішені.

Дослідження здійснюється на основі застосування фундаментальних положень економічної теорії, теорії фінансів, державного регулювання економіки, а також сучасні концепції аналізу та контролю. За допомогою системного аналізу і синтезу досліджено теоретичні підходи до визначення сутності фінансового контролю суб'єктів господарювання, виокремлено його суб'єктно-об'єктну та предметну структуру, а також складові забезпечення. Системно-структурний аналіз використано для обгрунтування наукового підходу до формування системи фінансового контролю на рівні виробничих систем, графічний метод - для наочного зображення результатів дослідження і схематичної побудови теоретичних положень дослідження.

\section{2. Генезис наукових підходів у визначенні фінансового контролю}

Серед питань, які потребують більш поглибленого дослідження, варто виділити визначення сутності терміну «фінансовий контроль» як економічної категорії. Вищезгадане поняття поєднує в собі категорії «фінанси» і «контроль». Якщо в більшості наукової літератури сформований єдиний підхід до визначення поняття «фінанси», що є економічними (грошовими) відносинами, пов'язаними з формуванням, розподілом та використанням грошових фондів і доходів, то трактування терміну «контроль» має різну спрямованість. 


\section{Chapter «Economic sciences»}

Формування понятійно-категорійного апарату щодо визначення терміну «контроль» дає підстави здійснювати дослідження в межах різних аспектів: фінансових, управлінських, правових, соціологічних, бухгалтерського обліку тощо.

На важливості дослідження контролю для подальшого розвитку багатьох наук наголошував 3. В. Гуцайлюк, стверджуючи що «контроль $\epsilon$ основою не лише для визначення чи уточнення цілей виконавчої діяльності, а й для стимулювання іiї виконання, тобто контроль корелює дієвість» [1, с. 145].

Разом із тим, незважаючи на підвищений інтерес зі сторони науковців та існування потреби у практиків у впровадженні дієвих механізмів контролю на підприємствах, все ж не поодинокими є випадки розгляду контролю в аспекті використання відповідної радянської парадигми, що розглядає державу в якості користувача контролю. Відповідно до цього, мета, основні завдання, принципи, інструменти та заходи контролю орієнтовані на задоволення потреб держави як власника бізнесу. Водночас існуючі напрацювання 3 приводу адаптації світового досвіду на певних рівнях функціонування контролю характеризуються вибірковістю та нерозвиненістю підходів щодо систематизації основних принципів та понятійно-категорійного апарату, а саме, ототожненням управлінського контролю, управлінського обліку, внутрішнього контролю та економічного контролю загалом.

Опрацювання вітчизняної та зарубіжної наукової літератури щодо визначення сутності понять «фінансовий контроль» та «контроль» дає підстави внести роз'яснення щодо визначення даних термінів, котрі $€$ хоч і спорідненими економічними категоріями у фінансах, з точки зору, науки, проте, звертаючи увагу на їх широке поле використання, в залежності від особливостей та місця застосування дані поняття мають дещо різні тлумачення.

Етимологію поняття «контроль» сучасні науковці розкривають, фор-муючи різні підходи. Так, В.О. Шевчук, досліджуючи походження контролю, логічним шляхом формує викладення своїх думок, з'ясувавши, що цей термін «має латинське походження, утворене шляхом сполучення слів: rola, яке означає згорток паперу із записами, документ, та contra, тобто протиставлення, яке висувається проти тверджень, що містяться в цьому документі. Таким чином, термін «controla» слід тлумачити як порівняння (зіставлення чи проотиставлення) кіль- 


\section{Datsenko Hanna}

кох тверджень» [2]. На противагу зазначеному підходу, Т.В. Антіповою досліджено відсутність такого слова в латинській мові, так як найближчим за смислом $\epsilon$ contra-lego (лат.) - проводити перевірочне читання, зчитувати (з рукописом) [3]. Припущення Є.В. Коврякової грунтуються на тому, що слово «контроль» пішло від однокореневого contrerôle (франц. - протисвиток), що пояснюється записами стародавніх документів на папірусних згортках, які розривалися навпіл, а кожна половинка зберігалася у зацікавленої особи. У випадку необхідності підтвердження достовірності документа одна 3 половинок свитку суміщалася з іншою, що свідчило про його непідробність. Отже, «контроль» розумівся як встановлення правильності обставин та справи.

В юридичній енциклопедії контроль (controle (франц.) - перевірка, від старофранц. controle-role - список, що має дублікат для перевірки) трактується як перевірка виконання законів, рішень тощо [4].

Таким чином, зважаючи на аналіз етимології поняття «контроль», можна стверджувати, що у широкому розумінні його трактують як процес, спрямований на встановлення відповідності функціонування об'єкта управління прийнятим управлінським рішенням, будучи орієнтованим на успішне досягнення поставленої мети. Як самостійній функції (етапу) управління і особливому виду діяльності, контролю притаманні конкретний зміст, цільова спрямованість та способи іiі реалізації.

У загальному вигляді контроль $\epsilon$ однією із функцій управління, про-явом якої є моніторинг процесу функціонування об'єкта управління $з$ метою оцінювання вагомості та результативності прийнятих управлінських рішень, виявлення відхилень від цих рішень та здійснення коригуючих заходів.

В свою чергу, економічна енциклопедія визначає контроль в межах двох аспектів:

1) як елемент управління економічними об'єктами і процесами, який полягає у нагляді за ними з метою перевірки їх відповідності стану, передбаченому законами, юридичними нормативними актами, а також програмами, планами, договорами, проектами, угодами;

2) як контроль за об'єктом, реальна влада, зосередження прав управління в одних руках.

У таблиці 1 представлено різноманітні точки зору вчених-економістів та практиків стосовно визначення сутності поняття «контроль». 


\section{Chapter «Economic sciences»}

Знову ж таки, як показує аналіз, одностайності думок учених стосовно визначення сутності поняття «контроль» не існує. Думки науковців стосовно даної дефініції різняться, оскільки контроль визначають як засіб, чинник, форму, елемент, функцію, процес, результат, діяльність, систему, зворотний зв'язок, умову, регулятор, гарант, явище, інститут, метод, правомочність, атрибут тощо.

Багатогранність підходів не свідчить про прагнення дати універсальне визначення терміну «контроль», адже скоріше за все це $\epsilon$ наслідком розгляду даної категорії через призму різних наукових напрямів - управлінських, філософських, соціологічних, аналітичних, правових, кібернетики тощо. Проте, не дивлячись на те, що визначення контролю, як і будь-якого поняття, що містить в собі різноманітність підходів, не може містити його вичерпної характеристики, тим не менш, воно має бути наділене певними рисами, сутністю, визначати мету, основні завдання та напрями реалізації.

Таблиця 1

\section{Систематизація наукових трактувань щодо сутності категорії «контроль»}

\begin{tabular}{|c|c|c|}
\hline Підхід & Автор, джерело & Визначення поняття «контроль» \\
\hline \multirow{4}{*}{ 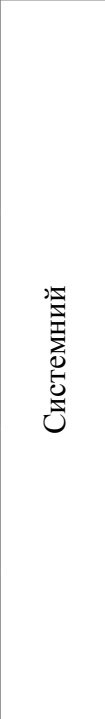 } & $\begin{array}{l}\text { I.В. Басанцов } \\
{[5, \text { с. } 18]}\end{array}$ & $\begin{array}{l}\text { Є системою спостереження та перевірки процесу } \\
\text { функціонування та фактичного стану об’єкта } \\
\text { управління з метою виявлення обгрунтованості й } \\
\text { ефективності прийняття управлінських рішень, } \\
\text { інформування про ці явища керівних органів з метою } \\
\text { уникнення або ліквідації несприятливих подій. }\end{array}$ \\
\hline & Т.М. Білуха [6] & $\begin{array}{l}\text { Це система нагляду та перевірки узгодженості } \\
\text { процесу функціонування об’єкта управління } \\
\text { прийнятим управлінським рішенням, } \\
\text { встановлення результатів управлінського впливу } \\
\text { виявленням відхилень, допущених у процесі } \\
\text { прийняття таких рішень. }\end{array}$ \\
\hline & $\begin{array}{c}\text { С.О. Булгакова } \\
{[7, \text { с. } 10]}\end{array}$ & $\begin{array}{l}\text { Є системою спостереження і перевірки процесу } \\
\text { функціонування відповідного об’єкта з метою } \\
\text { встановлення його відхилень від заданих } \\
\text { параметрів. }\end{array}$ \\
\hline & $\begin{array}{l}\text { Т.О. Губанова } \\
{[8, \text { с. } 72]}\end{array}$ & $\begin{array}{l}\text { Це складна, динамічна саморегулююча система, } \\
\text { яка складається з сукупності елементів, } \\
\text { пов’язаних спільною функцією, які знаходяться } \\
\text { у постійній взаємодії один з одним. }\end{array}$ \\
\hline
\end{tabular}


Продовження таблиці 1

\begin{tabular}{|c|c|c|}
\hline Підхід & Автор, джерело & Визначення поняття «контроль» \\
\hline \multirow[b]{2}{*}{ 罖 } & $\begin{array}{l}\text { В.А. Лушкін, } \\
\text { В.Д. Понікаров, } \\
\text { І.В. Ялдін, } \\
\text { А.С. Ачкасов } \\
\text { [9, с. 7] }\end{array}$ & $\begin{array}{l}\text { Це система спостереження та перевірки } \\
\text { процесу функціонування, а також фактичного } \\
\text { стану об'єкта управління з метою визначення } \\
\text { обгрунтованості і ефективності прийняття } \\
\text { управлінських рішень, інформування про } \\
\text { ці явища керівних органів та усунення } \\
\text { несприятливих ситуацій. }\end{array}$ \\
\hline & $\begin{array}{l}\text { Авторське } \\
\text { визначення }\end{array}$ & $\begin{array}{l}\text { Це система, яка складається з сукупності } \\
\text { елементів, які знаходяться у постійній взаємодії } \\
\text { один з одним і пов'язані між собою таким чином, } \\
\text { що здатні забезпечити збір необхідної інформації } \\
\text { про стан відповідного об'єкта, спостереження } \\
\text { і перевірку його функціонування за певним } \\
\text { процесом контролюючими органами, установами, } \\
\text { уповноваженими особами з метою встановлення } \\
\text { його відхилень від заданих параметрів, що в } \\
\text { подальшому формує підгрунтя для прийняття } \\
\text { управлінських рішень з метою досягнення високої } \\
\text { результативності функціонування об’єкта. }\end{array}$ \\
\hline \multirow{6}{*}{ 焉 } & $\begin{array}{c}\text { Ф.Ф. Бутинець, } \\
\text { С.В. Бардаш, } \\
\text { Н.М. Малюга } \\
\text { та Н.І. Петренко } \\
\text { [15, с. 10] }\end{array}$ & $\begin{array}{l}\text { Процес перевірки діяльності об’єкта контролю } \\
\text { з метою встановлення відхилень від заданих } \\
\text { параметрів. }\end{array}$ \\
\hline & $\begin{array}{l}\text { Вітвицька Н.С., } \\
\text { Чумакова I.Ю., } \\
\text { Коцупатрий М.М., } \\
\text { Фенченко М.Т. [11] }\end{array}$ & $\begin{array}{l}\text { Процес, спрямований на забезпечення } \\
\text { відповідності функціонування об'єкта } \\
\text { управління прийнятим управлінським рішенням } \\
\text { з метою успішного досягнення поставленої мети. }\end{array}$ \\
\hline & А. Гриліцька [10] & $\begin{array}{l}\text { Процес перевірки функціонування певного } \\
\text { об'єкта. }\end{array}$ \\
\hline & $\begin{array}{l}\text { Жила В.Г. } \\
{[12, \text { с. } 4]}\end{array}$ & $\begin{array}{l}\text { Процес, що забезпечує відповідність } \\
\text { функціонування об'єкта управління прийнятим } \\
\text { управлінським рішенням та спрямований на } \\
\text { успішне досягнення поставлених цілей. }\end{array}$ \\
\hline & $\begin{array}{l}\text { Ф.О. Журавка, } \\
\text { Л.А. Могила } \\
{[13, \text { с. } 4]}\end{array}$ & $\begin{array}{l}\text { Процес, що забезпечує відповідність } \\
\text { функціонування об'єкта управління прийнятим } \\
\text { управлінським рішенням та направлений на } \\
\text { успішне досягнення поставлених цілей. }\end{array}$ \\
\hline & Й.С. Завадський [14] & $\begin{array}{l}\text { Процес встановлення відповідності діяльності } \\
\text { об’єкта визначеним стандартам та нормативам } \\
\text { для виявлення та корегування будь-яких } \\
\text { відхилень. }\end{array}$ \\
\hline
\end{tabular}




\begin{tabular}{|c|c|c|}
\hline & & Закінчення таблиці 1 \\
\hline Підхід & Автор, джерело & Визначення поняття «контроль» \\
\hline \multirow{3}{*}{ 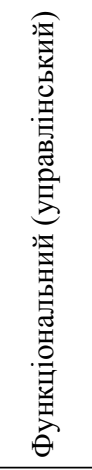 } & $\begin{array}{l}\text { Г.В. Атаманчук [17], } \\
\text { В.Б. Авер'янова [16], } \\
\text { С.М. Лайчук [20] }\end{array}$ & Загальна функція управління. \\
\hline & $\begin{array}{l}\text { О.Ю. Грачова } \\
{[18, \text { с. } 75]}\end{array}$ & $\begin{array}{l}\text { Етап та функція управління будь-якою } \\
\text { системою. }\end{array}$ \\
\hline & $\begin{array}{l}\text { Л.В. Дікань, } \\
\text { Ю.О. Голуб, } \\
\text { Н.В. Синюгіна [19] }\end{array}$ & $\begin{array}{l}\text { Є окремою функцією управління, що полягає } \\
\text { в систематизованому спостереженні за об'єктом } \\
\text { контролю, виявленні відхилень від заданих } \\
\text { параметрів, яка здійснюється } \\
3 \text { метою забезпечення ефективної діяльності } \\
\text { господарського суб’єкта через виконання } \\
\text { завдань, які стоять перед системою управління } \\
\text { таким суб'єктом. }\end{array}$ \\
\hline \multirow{3}{*}{ 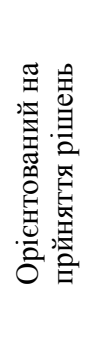 } & $\begin{array}{l}\text { П.А. Ореховський } \\
{[23]}\end{array}$ & Діяльність з виконання прийнятих рішень. \\
\hline & $\begin{array}{l}\text { Ю.С. Шемшученко } \\
\text { [4] }\end{array}$ & $\begin{array}{l}\text { Платформа для прийняття та реалізації рішень } \\
\text { в сфері господарської та фінансової діяльності } \\
\text { об'єкта. }\end{array}$ \\
\hline & $\begin{array}{l}\text { В.К. Гіжевський, } \\
\text { В.В. Головченко, } \\
\text { В.С. Головченко, } \\
\text { В.С. Ковальський [24] }\end{array}$ & $\begin{array}{l}\text { Основа реалізації рішень для усунення } \\
\text { виявлених недоліків та організації роботи } \\
\text { об’єкта в майбутньому. }\end{array}$ \\
\hline
\end{tabular}

Узагальнення наукових поглядів щодо поняття «контроль» вітчизняними та зарубіжними вченими та дослідниками дає можливість виокремити чотири основні підходи до його трактування: процесний, системний, функціональний (управлінський), а також підхід, котрий орієнтований на прийняття рішень. Таку тенденцію можна пояснити тим, що контроль $є$ багатогранною та різнофункціональною економічною категорією.

Розуміння контролю як системи характеризує дане поняття як сферу діяльності органів державної влади та фінансового управління. Системний підхід є найбільш прийнятним для юристів, соціологів та економістів, які досліджують контроль як ієрархію, взаємозалежність усіх складових відповідної державно-управлінської діяльності [5-9]. Проте суттєвим недоліком зазначеного підходу є те, що функціональні зв'язки або функції окремих компонентів та підсистем у цьому випадку часто залишаються невизначеними. 


\section{Datsenko Hanna}

В свою чергу, процесний підхід до визначення поняття «контроль» обумовлений необхідністю здійснення діагностики стану об'єктів, що досліджуються, на основі процесних методів збору даних за попередньо визначеними параметрами та проводити подальше управління в разі існування відхилень від планових показників [10-15].

Якщо розглядати контроль з точки зору функціонального підходу, а саме, як функції управління, то дане поняття не варто трактувати як окремий, несистемний метод, оскільки в цьому випадку контроль $\epsilon$ самостійною функцією менеджменту. Таке твердження обумовлене тим, що, починаючи з етапу проведення спостереження і закінчуючи етапом прийняття управлінських рішень, контроль характеризується своєю цілеспрямованістю, а отже, є окремою функцією управління [16-20].

Підтвердженням цих думок слугують судження таких вчених як В.К. Симоненко, О.І. Барановський та П.С. Петренко: «контроль не може бути зведений до методу або форми управлінської діяльності. Він $\epsilon$ самос-тійною функцією управління, отже особливим видом діяльності, який ха-рактеризується цільовою спрямованістю, однорідністю змісту й однотипністю способів його існування» [21, с. 7]. Ми погоджуємось 3 дум-кою авторів, оскільки такий підхід дозволяє здійснити перевірку виконання кожного конкретного управлінського рішення, а не розглядати контроль як цілеспрямований і відносно відокремлений вид управлінської діяльності. Таким чином, контроль трактується як специфічна функція управлінського циклу. Разом із тим, Е.М. Коротков, досліджуючи контроль, справедливо визначає його як одну з основних функцій управління, наголошуючи на здійсненні нею спостереження за керованими процесами, перевірку якості встановлення відхилень, збір необхідної інформації для оцінки ситуації [22]. Таке трактування є неповним по відношенню до визначення сутності контролю, оскільки керівник, виконуючи функцію контролю, не звужує свою діяльність лише до збору інформації та оцінки ситуації на підставі отриманих даних. Ми вважаємо, що одержана інформація має слугувати підгрунтям для прийняття рішення управлінського характеру. Залежно від того, якою буде отримана інформація при здійсненні контролю: (негативною, позитивною, повною, достовірною чи недостатньо якісною тощо) визначається форма і якість прийнятого рішення. 


\section{Chapter «Economic sciences»}

Виокремлення ще одного підходу, який трактує контроль як платформу для прийняття рішень [4; 23-24], обумовлене тим, що можливим $є$ прийняття певних рішень безпосередньо на основі отриманих результатів від проведеного контролю. При цьому вони можуть визначатись як управлінським, так і організаційним чи економічним спрямуванням, що забезпечує ефективність використання наявних ресурсів як на макро-, так і на мікрорівні.

Аналізуючи термін контроль, варто зауважити, що науковці не прит-римуються єдиного підходу щодо дослідження даного поняття. Так, зокрема, М.Ю. Павлюк, котрий визначає контроль як «елемент управління, що є складним процесом, спрямованим на перевірку відповідності контрольованих об'єктів вимогам, встановленим параметрам», вміщує в собі як процесний, так і функціонально-управлінський підходи. В свою чергу, Т.В. Литвинчук, котрий визначає контроль як «форму зворотного зв'язку, за допомогою якої керуюча система одержує необхідну інформацію про дійсний стан керованого об'єкту та використання управлінських рішень», використовує як систем-ний підхід, так і слугує платформою для прийняття та реалізації управлінських рішень. В.О. Шевчук схильний вважати, що контроль $\epsilon$ протистоянням, яке висувається проти тверджень, що знаходяться в документах [2].

Таким чином, систематизація наукових підходів щодо трактування сутності поняття «контроль» дає підстави, в першу чергу, визначити дану категорію як взаємозв'язок і взаємодію об'єктів, суб'єктів, методів, форм, інструментів, що в сукупності формують комплекс елементів (кожен 3 цих елементів має свої особливості, поділ яких здійснюється за певними класифікаційними ознаками) 3 приводу перевірки ходу функціонування відповідного об'єкта з метою встановлення його відхилень від заданих параметрів. Крім того, при визначенні поняття «контроль» багатьма дослідниками не вказується, на кого мають бути покладені обов'язки щодо здійснення спостереження та перевірки певного процесу у функціонуванні об'єкта. Так, зокрема, такими повноваженнями можуть бути наділені контролюючі органи, установи або уповноважені особи. Разом із тим, не всі дослідники вказують, якою є мета виявлення прогалин у функціонуванні об’єкта. Враховуючи різнобічність та неоднозначність думок дослідників щодо дослідження категорії «контроль», сформоване автором визначення полягає 


\section{Datsenko Hanna}

у наступному: контроль - це система, яка складається з сукупності елементів, які знаходяться у постійній взаємодії один з одним і пов'язані між собою таким чином, що здатні забезпечити збір необхідної інформації про стан відповідного об'єкта, спостереження і перевірку його функціонування за певним процесом контролюючими органами, установами, уповноваженими особами з метою встановлення його відхилень від заданих параметрів, що в подальшому формує підгрунтя для прийняття управлінських рішень 3 метою досягнення ви-сокої результативності функціонування об'єкта.

На вагомості контрольної діяльності для економіки та суспільства на-голошувалось ще в Лімській декларації керівних принципів аудиту державних фінансів, прийнятій IX конгресом Міжнародної організації вищих органів фінансового контролю (INTOSAI) в 1977 р. [25], в якій стверджувалось, що здійснення контролю $є$ обов'язковим елементом управління громадськими фінансовими коштами, оскільки таке управління несе за собою відповідальність перед суспільством.

Разом із тим, в ході подальших досліджень нами було виявлено відсутність загальноприйнятого визначення фінансового контролю як важливої категорії фінансової науки, що пояснюється іiї комплексністю та інтегральністю, зумовлюючи своєрідну багатогранність і певну суперечливість підходів щодо дослідження даного поняття.

На неоднозначності трактування зазначеного поняття наголошує Л.А. Савченко, пояснюючи це тим, що фінансовий контроль $є$ своєрідним видом контролю, що має складну структуру, а тому його прояв відбувається у різних аспектах [26].

Так, систематизація наукових поглядів вчених щодо тлумачення фінансового контролю дає підстави стверджувати щодо різнобічності думок вчених стосовно даного поняття: одними науковцями фінансовий контроль визначається як діяльність, іншими - як функція управління, третіми - при трактуванні поняття використовують не зовсім коректну термінологію, вказуючи, що фінансовий контроль - це контроль, четверті - ототожнюють фінансовий контроль 3 наглядом.

Необхідність цілісного уявлення щодо тлумачення поняття «фінансо-вий контроль» викликана існуванням системного підходу [27-31], що наділений суттєвою перевагою до розуміння змісту зазначеної категорії, оскільки дозволяє сформувати ієрархію, взаємозалежність усіх елементів відповідної управлінської діяльності. Виходячи з пред- 


\section{Chapter «Economic sciences»}

ставлених поглядів прихильників зазначеного підходу можна зробити висновок щодо неможливості здійснення управлінської діяльності за межами системи, а отже, можна говорити і про відсутність контролю поза системою. Через те, за нашими переконаннями, реалізовуючи свою управлінську функцію, фінансовий контроль може здійснюватися лише в межах самостійної системи. Отже, систематизація наукових поглядів вчених-економістів дає підстави звести поняття «фінансовий контроль» до сформованого автором визначення: система, яка складається з сукупності елементів, які перебувають у взаємозв'язку та взаємозалежності, і об’єднані в спільну функцію управління, що забезпечує отримання інформації про об'єкт управління в результаті контролю, та на цій основі прийняття рішень щодо виявлення і усунення відхилень у функціонуванні об'єкта управління, що забезпечується законодавчими і виконавчими органами влади всіх рівнів, а також спеціально створеними службами установ та організацій, відділами підприємств чи окремими контролюючими особами 3 метою забезпечення ефективного функціонування об'єкта та задоволення інтересів як держави, так і суб’єктів господарювання.

\section{3. Особливості організації фінансового контролю суб'сктів господарювання}

В ході подальших досліджень нами пропонується здійснити розмежування між фінансовим контролем на макро-, мезо- та мікрорівні. Так, на макрорівні основні інструменти фінансового контролю спрямовуються на підвищення ефективності функціонування економіки та забезпечення законних інтересів держави, суб'єктів господарювання та суспільства в цілому шляхом: забезпечення обігу фінансових ресурсів із дотриманням принципів законності, повноти та своєчасності сплати податків та обов'язкових платежів, блокування діяльності, що загрожує національній безпеці, призводить до монополізації ринків, організації забороненого державою виробництва товарів і надання послуг тощо; на мезорівні - фінансовий контроль здатен виявляти порушення на галузевому та регіональному рівнях; на мікрорівні - фінансовий контроль спрямовується на забезпечення дотримання правил ведення бухгалтерського обліку та фінансової звітності; соціальних гарантій працівників і своєчасної виплати заробітної плати; стандартів ціноутворення та встановлення тарифів, 


\section{Datsenko Hanna}

платіжної дисципліни; попередження фіктивних фінансових операцій i фактів відмивання «брудних» грошей; попередження та усунення фактів незаконного, нецільового і неефективного використання бюджетних коштів, переданих суб'єктам господарювання, фінансових ресурсів, які додатково отримують ці суб'єкти за пільгами з оподаткування; забезпечення дотримання порядку та процедур державних і комунальних закупівель, виявлення нецільового і неефективного використання майна державної і комунальної власності, нецільового використання кредитів і позик, отриманих під гарантії Уряду.

Особливий інтерес в рамках нашого дослідження представляє виокремлення виду фінансового контролю за такою класифікаційною ознакою як суб'єкт контролю. Так, державний фінансовий контроль, суб'єктами котрого є органи законодавчої й виконавчої влади, в першу чергу, спрямований на об'єкти, що підлягають контролю, незалежно від їх відомчого підпорядкування. Відомчий фінансовий контроль, що здійснюється контрольно-ревізійними службами галузевих міністерств, відомств, концернів та інших органів управління, свою сферу впливу поширює на виробничу і фінансову діяльність підвідомчих підприємств та установ. Внутрішньогосподарський фінансовий контроль, що здійснюється економічними службами підприємств, супроводжує повсякденну фінансово-господарську діяльність. Об'єктом тут виступає виробнича і фінансова діяльність самого підприємства, а також його структурних підрозділів (цехів, відділів, філій). Аудиторський (недержавний) фінансовий контроль, що може проводитися як за ініціативою суб'єкта господарювання, так і за рішенням органу державної влади, здійснюють незалежні аудитори або аудиторські фірми, які уповноважені суб'єктами господарювання на його проведення. Правова регламентація аудиторського контролю передбачена Законом України «Про аудит фінансової звітності та аудиторську діяльність» від 21.12.2017 [32]. Метою громадського фінансового контролю є виявлення і попередження різних порушень у фінансовій діяльності підприємств з ініціативи окремих груп громадян. Цей вид фінансового контролю здійснюється громадськими організаціями (партіями, рухами, профспілковими організаціями); може проводитися групами фахівців, які створюються безпосередньо на підприємствах.

Існують ще наступні види фінансового контролю: контроль фінансово-кредитних установ (здійснюється за діяльністю суб'єктів фінан- 


\section{Chapter «Economic sciences»}

сових відносин з приводу дотримання фінансово-кредитного законодавства); муніципальний (контроль органів місцевого самоврядування, який здійснюють органи представницької і виконавчої влади місцевих рад через відповідні комісії і місцеві фінансові органи). Враховуючи те, що практика реалізації громадського контролю на підприємствах не набула свого поширення (зважаючи на неспроможність правильної його організації та розподілу ролей, а також ускладненість процесу щодо призначення компетентних суб'єктів фінансового контролю), а також те, що контроль фінансово-кредитних установ та муніципальний контроль не стосуються безпосередньо підприємств, пи-тання щодо доцільності їх розгляду в рамках тематики нашого дослідження виключається.

Зважаючи на розгляд автором фінансового контролю виробничих систем як елементів, які у сукупності забезпечують його дієвість та ефективність функціонування, структурна побудова системи фінансового контролю, подана на рис. 1, містить в собі такі важливі компоненти, які мають бути представлені у будь-якій функціонуючій системі: вхід (інформаційне забезпечення контрольної діяльності), вихід (продукт функціонування системи фінансового контролю, що забезпечується важелями впливу, за реалізацією котрих здійснюється обробка інформації з метою прийняття оптимальних управлінських рішень на основі отриманих результатів). Зауважимо, що підтримка системи фінансового контролю виробничих систем забезпечується інформаційними потоками: про якість заходів фінансового контролю, вжитих суб'єктами регулювання, а також про стан дотримання об'єктами фінансового контролю встановлених правил формування і використання фінансових ресурсів. В межах наших досліджень розробка системи фінансового контролю виробничих систем повинна призводити до розробки механізму, котрий перетворює вхід системи в ії вихід, та розкривається у здійсненні контрольних процедур, які повинні перебувати у взаємоузгодженості із цілями та завданнями фінансового контролю.

Використання системного підходу до визначення основних складових фінансового контролю дозволило побудувати структурнологічну схему фінансового контролю на рівні суб'єктів господарювання, 3 виокремленням основних завдань проведення, суб'єктно-об'єктного складу, інструментів та важелів реалізації, представлених на рис. 2. 


\section{Datsenko Hanna}

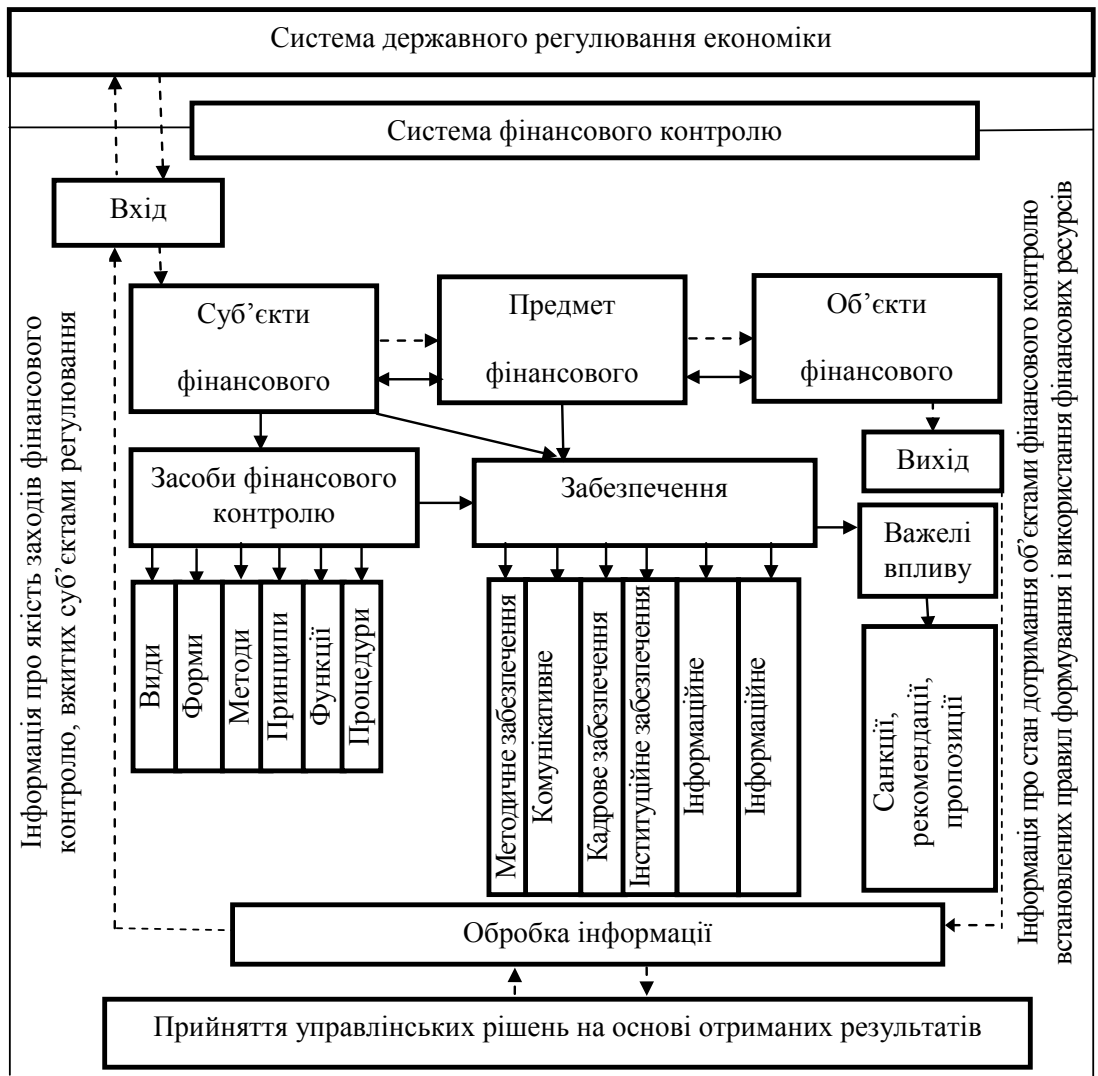

Рис. 1. Структурна побудова системи фінансового контролю суб'єктів господарювання

Виходячи із зазначеного, можна зробити висновок, що фінансовий контроль $є$ невід'ємним структурним елементом державного регулювання економіки, оскільки покликаний забезпечити цей процес, що виражається метою фінансового контролю та сформувати необхідні заходи для блокування негативних явищ і профілактики їх на майбутнє. Отримана інформація в результаті проведеного фінансового контролю також може бути використана для своєчасного вжиття заходів з блокування негативних явищ та недопущення їх у майбутньому в практиці державного регулювання економіки. 


\section{Chapter «Economic sciences»}

Звідси роль фінансового контролю в системі державного регулювання економіки визначається через участь у розв'язанні двох проблем: підвищенні ефективності державного регулювання економіки; дотриманні правил формування і використання фінансових ресурсів, встановлених державою. Беручи до уваги зазначене, ефективно проведений фінансовий контроль на рівні підприємства впливає як на задоволення потреб та інтересів суб'єктів господарювання, так і підвищення економічного розвитку держави в цілому.

Ключовим моментом у проведенні фінансового контролю на підприємствах є те, що перевірку здійснюють не лише на дотримання відповідності ведення фінансово-господарської діяльності вимогам чинного законодавства, а й ефективність витрачання коштів (у випадку підприємств державної форми власності - державних коштів). Важелі, які застосовуються до об'єктів фінансового контролю можуть бути як позитивними (пропозиції та приписи об'єктам фінансового контролю щодо поліпшення їх діяльності, з точки зору, іiі ефективності та результативності, здебільшого використовуються при проведенні внутрішньогосподарського та аудиторського фінансового контролю при пошуку недоліків у його роботі та розробці пропозицій щодо вдосконалення), так і негативними (санкції, різноманітні за своїми властивостями та аналогічні за призначенням - покарання: фінансові, адміністративні, кримінальні, дисциплінарні тощо.

Таким чином, фінансовий контроль, за умови правильного та обгрунтованого планування та прийняття заходів, спрямованих на підвищення фінансово-господарської діяльності суб'єктів господарювання, сприяє виробничому та соціальному зростанню, забезпечуючи досягнення стратегічних цілей економічного розвитку держави.

Водночас 3 метою підвищення ефективності реалізації фінансового контролю необхідно адаптувати вітчизняне законодавство до європейських вимог, здійснювати ретельний підбір висококваліфікованих кадрів до служб, які несуть відповідальність за реалізацію функції контролю, підвищувати значимість фінансового контролю (як загальнодержавного та відомчого, так і внутрішньогосподарського та аудиторського) на всіх етапах здійснення заходів, спрямованих на ефективне функціонування суб' єктів господарювання та прискорення економічного розвитку національної економіки. 


\section{Datsenko Hanna}

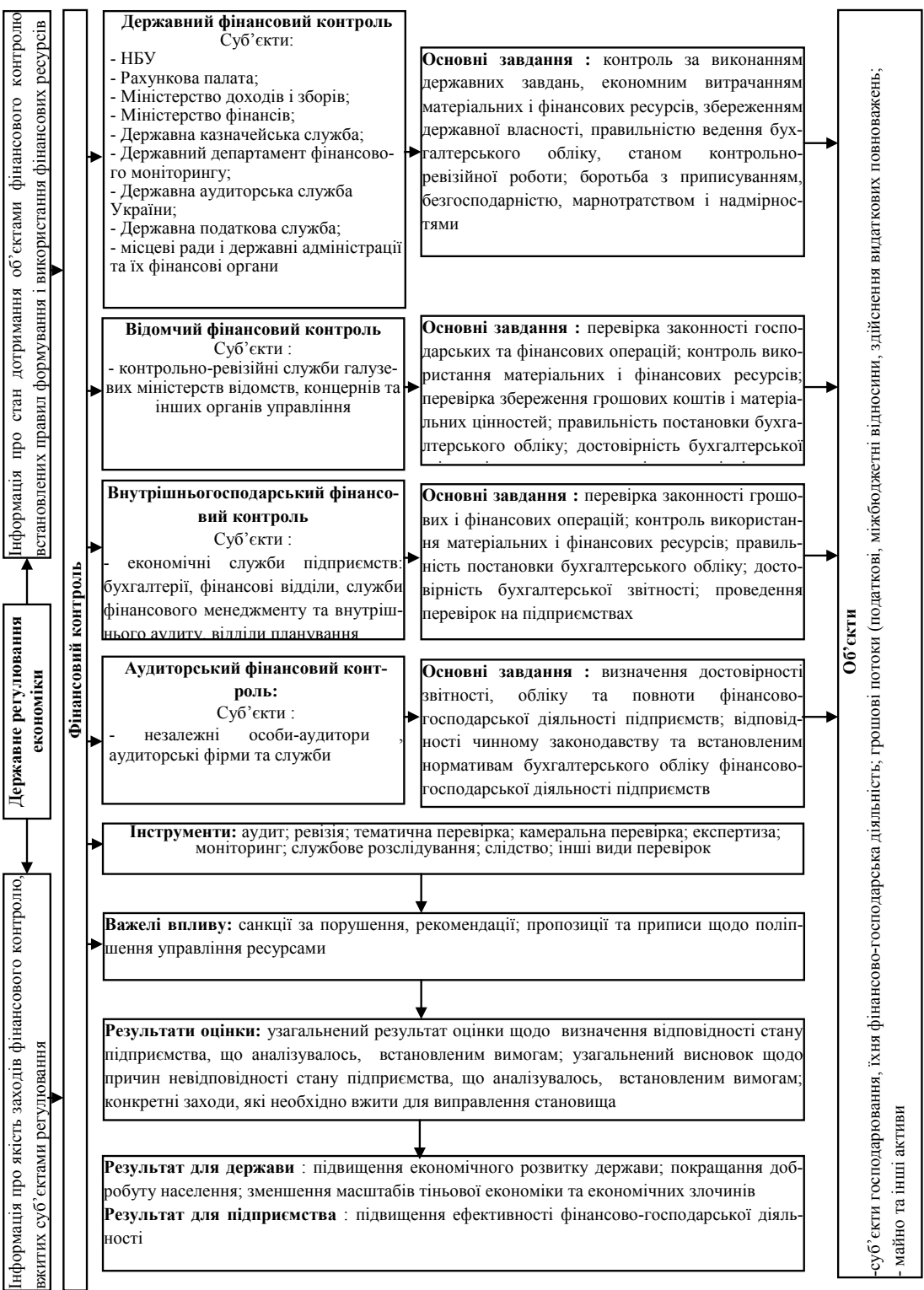

\section{Рис. 2. Система фінансового контролю на рівні суб’єктів господарювання}




\section{Chapter «Economic sciences»}

\section{4. Результати дослідження}

Отримані результати дослідження дають підстави стверджувати про пе-реваги системного підходу щодо визначення поняття «фінансовий контроль», який уможливлює формування ієрархії та взаємозалежності усіх елементів відповідної управлінської діяльності. Схильність автора до зазначеного підходу в аспекті розгляду цієї економічної категорії пояснюється неможливістю здійснення управлінської діяльності за межами системи, а отже, і про відсутність фінансового контролю поза системою. Через те, дослідження генезису наукових підходів у визначенні терміну «фінансовий контроль» підтверджує реалізацію ним своєї управлінської функції лише в межах самостійної системи. Це дало змогу запропонувати авторське визначення термінів «контроль» та «фінансовий контроль». За результатами досліджень доведено, що кінцевою метою здійснення контролю $є$ формування раціональних рішень управлінського характеру з метою забезпечення ефективного функціонування об'єкта та забезпечення ним високих результатів в економічному, соціальному, політичному, науково-технічному та інших напрямах розвитку. В ході подальших досліджень здійснено розмежування між фінансовим контролем на макро-, мезо- та макрорівні. Схематично представлено структурну побудову системи фінансового контролю, що містить елементи, які у сукупності забезпечують його дієвість та ефективність функціонування. Це дозволяє в подальшому розробити механізм, котрий перетворює вхід системи в ії вихід, тим самим забезпечуючи прийняття ефективних управлінський рішень на основі отриманих результатів. Використання системного підходу до визначення основних складових фінансового контролю дозволило побудувати структурнологічну схему фінансового контролю на рівні суб'єктів господарювання, з виокремленням основних завдань проведення, суб'єктно-об'єктного складу, інструментів та важелів реалізації. Це забезпечить отримання позитивних результатів як для суб' єктів господарювання, так і для держави в цілому.

\section{5. Висновки}

Таким чином, фінансовий контроль, який здійснюється як на загальнодержавному та регіональному рівнях, так і на рівні спеціально створених служб установ та організацій, відділів підприємств чи окремих контролюючих осіб, дозволяє здійснювати моніторинг за виконанням 


\section{Datsenko Hanna}

запланованих програм, своєчасно виявляти відхилення від запланованих показників, здійснювати пошук причин їх виникнення, об’єктивно оцінювати економічну ефективність фінансово-господарської діяльності господарюючих суб’єктів, розробляти заходи своєчасного реагування, коригувати заплановані результати і вносити зміни до формування стратегічних цілей і орієнтирів, що забезпечують ефективне функціонування об'єкта фінансового контролю та задоволення інтересів як держави, так і суб'єктів господарювання. Результати подальших досліджень автора полягають у вивченні особливостей національної системи фінансового контролю та адаптації прогресивного міжнародного досвіду в цій сфері, спрямованого на формування векторів модернізації вітчизняної системи фінансового контролю як на рівні держави, так і на рівні суб’ єктів господарювання.

\section{Список літератури:}

1. Гуцайлюк 3.В. Облік і контроль у ринковій економіці: елементи концепції: монографія / 3.В. Гуцайлюк. - Тернопіль: Крок, 2013. - 176 с.

2. Шевчук О.А. Державний фінансовий контроль: питання теорії та практики: монографія / О.А. Шевчук. - Київ: УБС НБУ, 2013. - 431 с.

3. Антипова Т.В. Теория и методология государственного аудита получателей федеральных бюджетных средств : дис. ... доктора эконом. наук : 08.00.12 / Антипова Татьяна Валентиновна. - Москва, 2008. - 380 с.

4. Юридична енциклопедія / Ю.С. Шемшученко. - Київ: Укр. енцикл., 2001. - T. 3: К-М., 2001. - Т. 2. - 792 с.

5. Басанцов I.В. Розвиток державного фінансового контролю в умовах ринкової економіки України: автореф. дис. на здобуття наук. ступеня д-ра екон. наук: спец. 08.00.08 - гроші, фінанси і кредит / I.В. Басанцов. - Ірпінь: Національний університет ДПС України, 2008. - 34 с.

6. Білуха М. Функції фінансово-господарського контролю й аудиту у формуванні ринкових відносин / М. Білуха, Л. Зайцев // Бухгалтерський облік і аудит. - 1996. - № 9. - С. 6-10.

7. Булгакова С. Удосконалення державного фінансового контролю / С. Булгакова, Н. Яковлева // Вісник Київського національного торгівельноекономічного університету. - 2003. - № 1. - С. 28-32.

8. Губанова Т.О. Правове забезпечення державного фінансового контролю в Україні : автореф. дис. на здобуття наук. ступеня канд. екон. наук : спец.12.00.07 / Т.О. Губанова ; КМ України, Нац. ун-т біоресурсів і природокористування України. - Київ, 2013. - 20 с.

9. Лушкин В.А. Аудит : учеб. пособие для студ. экон. спец. / В.А. Лушкин, В.Д. Поникаров, И.В. Ялдин, А.Е. Ачкасов; Ин-т содержания и методов обучения, Харьк. гос. экон. ун-т, Харьк. гос. акад. нар. хоз-ва. - Житомир, 1999. $240 \mathrm{c}$. 


\section{Chapter «Economic sciences»}

10. Гриліцька А.В. Шляхи підвищення ефективності внутрішнього аудиту грошових коштів на підприємствах споживчої кооперації / А.В. Гриліцька // Облік, контроль і аналіз в управлінні підприємницькою діяльністю : матеріали III-ої Міжнародної науково-практичної конференції. - Черкаси: ЧДТУ, 2005. - С. 95-101.

11. Державний фінансовий контроль: навч.-метод. посіб. для 36 самост. вивч. дисципліни / Н.С. Вітвицька, І.Ю. Чумакова, М.М. Коцупатрий, М.Т. Фенченко. - Київ: КНЕУ, 2003. - 408 с.

12. Жила В.Г. Ревізія та аудит: навч. посібник / В.Г. Жила. - Київ: МАУП, 1998. $-96 \mathrm{c}$.

13. Журавка Ф.О. Сутність і роль фінансової безпеки суб'єкта підприємництва в контексті забезпечення його економічної безпеки / Ф.О. Журавка, Л.А. Могила // Проблеми і перспективи розвитку банківської системи України : зб. наук. праць / Державний вищий навчальний заклад «Українська академія банківської справи Національного банку України». - Суми, 2012. Вип. 35. - С. 16-24.

14. Завадський Й.С. Менеджмент. - Т. 1. - Київ: Українсько-фінансовий інститут менеджменту і бізнесу, 1997. - 543 с.

15. Усач Б.Ф. Контроль і ревізія / Б.Ф. Усач. - Київ: Знання Прес, 2002. $-253 \mathrm{c}$.

16. Авер'янов В.Б. Адміністративне право України / В.Б. Авер'янов. Київ: Юридична думка, 2004. - 584 с.

17. Атаманчук Г.В. Теория государственного управления : курс лекций / Г.В. Атаманчук. - Москва: Юрид. лит., 1997. - 400 с.

18. Грачева Е.Ю. Проблемы правового регулирования государственного финансового контроля / Е.Ю. Грачева. - Москва: Юриспруденция, 2000. $192 \mathrm{c}$.

19. Дікань Л.В. Державний аудит: навч. посіб. / Л.В. Дікань, Ю.О. Голуб, Н.В. Синюгіна. - Київ: Знання, 2011. - 503 с.

20. Лайчук С.М. Облік і контроль лізингових операцій : теорія і практика : автореф. дис. канд. екон. наук / С.М. Лайчук. - Київ: Східноукраїнський національний ун-т ім. Володимира Даля, 2002. - 20 с.

21. Барановський О.І. Проблеми фінансової безпеки в умовах інтеграції України у світовий фінансовий простір / O.І. Барановський // Вісник національного банку України. - 2003. - № 10. - С. 18-19.

22. Коротков Э.М. Исследование систем управления. - Москва: ДеКа, 2000. $-285 \mathrm{c}$.

23. Ореховський П.А. Контроллинг / П.А. Ореховський - Обнинск: МАСЗ, 2000. $-125 \mathrm{c}$.

24. Популярна юридична енциклопедія / В.К. Гіжевський, В.В. Головченко, В.С. Головченко, В.С. Ковальський. - Київ: Хрінком Інтер, 2002. - 528 с.

25. Лімська декларація керівних принципів аудиту державних фінансі. Рахункова палата України [Електронний ресурс]. - Режим доступу: http://www.ac-rada.gov.ua/

26. Савченко Л.А. Правові проблеми фінансового контролю в Україні : монографія / Л.А. Савченко. - Ірпінь: Академія ДПС України, 2001. - 408 с. 


\section{Datsenko Hanna}

27. Економічна енциклопедія: у трьох томах. Т. 1 / Ред. кол.: С.В. Мочерний (відп. ред.) та ін. - Київ: Академія, 2000. - 864 с.

28. Вознесенский Э.А. Финансовый контроль в СССР / Э.А. Вознесенский. - Москва: Юрид. лит., 1973. - 134 с.

29. Анисимов А.А. Финансовый контроль в капиталистических странах. Москва: Финансы, 1966. - 99 с.

30. Грязнова А.Г. Финансы / А.Г. Грязнова, Е.В. Маркина. - Москва: Финансы и статистика, 2006. - 504 с.

31. Стефанюк І.Б. Державний фінансовий контроль: проблеми ідентифікації й визначення системи / І.Б. Стефанюк // Фінанси України. - 2009. № $11 .-$ C. $12-19$.

32. Про аудит фінансової звітності та аудиторську діяльність : Закон України № 2258-VIII, від 21.12.2017 // Відомості Верховної Ради (ВВР). 2018. - № 9. - Ст. 50.

\section{References:}

1. Ghucajljuk Z.V. (2013). Oblik i kontrolj u rynkovij ekonomici: elementy konce-pciji: monoghrafija [Account and control in a market economy: elements of conception : monograph]. Ternopilj: Krok. (in Ukrainian)

2. Shevchuk O.A. (2013). Derzhavnyj finansovyj kontrolj: pytannja teoriji ta prak-tyky : monoghrafija [State financial control: question of theory and practice : monograph]. Kyiv: UBS NBU. (in Ukrainian)

3. Antipova T.V. (2008). Teoriya i metodologiya gosudarstvennogo audita polucha-teley federal'nykh byudzhetnykh sredstv [Theory and methodology of state audit of recipients of federal budgetary facilities] (PhD Thesis), Moskva.

4. Shemshuchenko Ju.S. (2001). Jurydychna encyklopedija [Legal encyclopaedia]. Kyiv: Ukr. encykl., vol. 3: K-M., vol. 2. (in Ukrainian)

5. Basancov I.V. (2008). Rozvytok derzhavnogho finansovogho kontrolju v umovakh rynkovoji ekonomiky Ukrajiny [Development of state financial control is in the conditions of market economy of Ukraine] (PhD Thesis), Irpinj: National university of Government tax service of Ukraine.

6. Bilukha M., Zajcev L. (1996). Funkciji finansovo-ghospodarsjkogho kontrolju $\mathrm{j}$ audytu $\mathrm{u}$ formuvanni rynkovykh vidnosyn [Functions of financiallyeconomic control and audit are in forming of market relations]. Bukhghaltersjkyj oblik $i$ audyt, no 9, pp. 6-10.

7. Bulghakova S., Jakovleva N. (2003). Udoskonalennja derzhavnogho finansovogho kontrolju [Functions of financially-economic control and audit are in forming of market relations]. Visnyk Kyivsjkogho nacionaljnogho torghiveljnoekonomichnogho universytetu, no 1, pp. 28-32.

8. Ghubanova T.O. Pravove zabezpechennja derzhavnogho finansovogho kontrolju v Ukrajini [The legal providing of state financial control is in Ukraine] (PhD Thesis), Kyiv: KM Ukrajiny, Nac. un-t bioresursiv i pryrodoko-rystuvannja Ukrajiny.

9. Lushkin V.A., Ponikarov V.D., Yaldin I.V., Achkasov A.E. (1999). Audit : ucheb. posobie dlya stud. ekon. spets. [Audit : tutorial for the students of economic 


\section{Chapter «Economic sciences»}

specialities]. Zhitomir: In-t soderzhaniya i metodov obucheniya, Khar'k. gos. ekon. un-t, Khar'k. gos. akad. nar. khoz-va. (in Russian)

10. Ghrylicjka A.V.(2005). Shljakhy pidvyshhennja efektyvnosti vnutrishnjogho audytu ghroshovykh koshtiv na pidpryjemstvakh spozhyvchoji kooperaciji [Ways of efficiency increase of internal audit of monetary resources on the enterprises of consumer co-operation]. Proceedings of the Oblik, kontrolj $i$ analiz $v$ upravlinni pidpryjemnycjkoju dijaljnistju : III Mizhnarodna naukovo-praktychna konferencija (Ukraine, Cherkasy, 2005), Cherkasy: ChDTU, pp. 95-101.

11. Vitvycjka N.S., Chumakova I.Ju., Kocupatryj M.M., Fenchenko M.T. (2003). Derzhavnyj finansovyj kontrolj: navch.-metod. posib. dlja 36 samost. vyvch. dyscypliny [State financial control: educational and methodical manual for a 36 independent study of disciplines]. Kyiv: KNEU. (in Ukrainian)

12. Zhyla V.Gh. (1998). Revizija ta audyt: navch. posibnyk [Revision and audit : educational manual]. Kyiv: MAUP. (in Ukrainian)

13. Zhuravka F.O., Moghyla L.A. (2012). Sutnistj i rolj finansovoji bezpeky sub'jekta pidpryjemnyctva $\mathrm{V}$ konteksti zabezpechennja jogho ekonomichnoji bezpeky [Essence and role of financial safety of business entity in the context of providing of economic security]. Problemy i perspektyvy rozvytku bankivsjkoji systemy Ukrajiny : zb. nauk. pracj, vol. 35, pp. 16-24.

14. Zavadsjkyj J.S. (1997). Menedzhment [Management]. Kyiv: Ukrajinsjkofinansovyj instytut menedzhmentu i biznesu. (in Ukrainian)

15. Usach B.F. (2002). Kontrolj i revizija [Control and revision]. Kyiv: Znannja Pres. (in Ukrainian)

16. Aver'janov V.B. (2004). Administratyvne pravo Ukrajiny [Administrative law of Ukraine]. Kyiv : Jurydychna dumka. (in Ukrainian)

17. Atamanchuk G.V. (1997). Teoriya gosudarstvennogo upravleniya : kurs lektsiy [A theory of state administration : a course of lectures]. - Moskva : Yurid. lit. (in Russian)

18. Gracheva E.Yu. (2000). Problemy pravovogo regulirovaniya gosudarstvennogo finansovogo kontrolya [Problems of the legal adjusting of state financial control]. Moskva : Yurisprudentsiya. (in Russian)

19. Dikanj L.V., Gholub Ju.O., Synjughina N.V. (2011). Derzhavnyj audyt: navch. posib. [State audit : educational manual ]. Kyiv: Znannja. (in Ukrainian)

20. Lajchuk S.M. (2002). Oblik i kontrolj lizynghovykh operacij: teorija i praktyka [An account and control of leasings operations: a theory and practice] (PhD Thesis), Kyiv: Eastern Ukrainian National University of Volodymyr Dahl.

21. Baranovsjkyj O.I. (2003). Problemy finansovoji bezpeky v umovakh integhraciji Ukrajiny u svitovyj finansovyj prostir [Problems of financial safety are in the conditions of integration of Ukraine in outer financial space]. Visnyk nacionaljnogho banku Ukrajiny, no 10, pp. 18-19.

22. Korotkov E.M. (2000). Issledovanie sistem upravleniya [Research of control system]. Moskva: DeKa. (in Russian)

23. Orekhovs'kiy P.A. (2000). Kontrolling [Controlling]. Obninsk: MASZ. (in Russian)

24. Ghizhevsjkyj V.K., Gholovchenko V.V., Gholovchenko V.S., Kovaljsjkyj V.S. (2002). Populjarna jurydychna encyklopedija [Popular Law Encyclopedia]. Kyiv: Khrinkom Inter. (in Ukrainian) 


\section{Datsenko Hanna}

25. Limsjka deklaracija kerivnykh pryncypiv audytu derzhavnykh finansiv. Rakhunkova palata Ukrajiny [The Lima Declaration on Guidelines for the Audit of Public Finances. Accounting Chamber of Ukraine]. Retrieved from: http://www.ac-rada.gov.ua/

26. Savchenko L.A. (2001). Pravovi problemy finansovogho kontrolju v Ukrajini : monoghrafija [Legal problems of financial control in Ukraine : monograph]. Irpinj: Akademija DPS Ukrajiny. (in Ukrainian)

27. Mochernyj S.V. (ed.) (2000). Ekonomichna encyklopedija [Economic encyclopaedia]. Kyiv: Akademija. (in Ukrainian)

28. Voznesenskiy E.A. (1973). Finansovyy kontrol' v SSSR [Financial control in the USSR]. Moskva: Yurid. lit. (in Ukrainian)

29. Anisimov A.A. (1966). Finansovyy kontrol' v kapitalisticheskikh stranakh [Financial control in the capitalist countries]. Moskva: Finansy. (in Russian)

30. Gryaznova A.G., Markina E.V. (2006). Finansy [Finances]. Moskva: Finansy i statistika. (in Russian)

31. Stefanjuk I.B. (2009). Derzhavnyj finansovyj kontrolj: problemy identyfikaciji j vyznachennja systemy [State financial control: problems of authentication and determination of the system]. Finansy Ukrajiny, no 11. pp. 12-19.

32. Pro audyt finansovoji zvitnosti ta audytorsjku dijaljnistj (2018) : Zakon Ukrajiny № 2258-VIII, vid 21.12.2017 [Law of Ukraine on the audit of the financial reporting and public accountant activity from December 21, 2017, no 2258-VIII]. Vidomosti Verkhovnoi Rady Ukrainy [Bulletin of Verkhovna Rada of Ukraine], no 9 , Art. 50. 